\title{
Critical assessment of the current understanding/ knowledge of the framework of the Ecosystem Approach to Fisheries in the Mediterranean and Black Seas
}

\author{
Paolo Sartor ${ }^{1}$, Francesco Colloca ${ }^{2}$, Christos Maravelias ${ }^{3}$, Francesc Maynou ${ }^{4}$ \\ ${ }^{1}$ CIBM Consorzio per il Centro Interuniversitario di Biologia Marina ed Ecologia Applicata, Viale Nazario Sauro 4, \\ 57128 Livorno, Italy. E-mail: psartor@ cibm.it \\ ${ }^{2}$ CNR-IAMC Istituto per l'Ambiente Marino Costiero, Sede di Mazara del Vallo, V. L. Vaccara 61, \\ 91026 Mazara del Vallo (TP), Italy. \\ ${ }^{3}$ HCMR Hellenic Centre for Marine Research, Institute of Marine Biological Resources, PO Box 2214, GR 71003, \\ Iraklion, Greece.
${ }^{4}$ Institut de Ciències del Mar, CSIC. Psg Marítim de la Barceloneta 37-49, 08003-Barcelona, Spain.
}

\begin{abstract}
Summary: A critical review was carried out involving experts from 17 countries, to identify, summarize and evaluate the current understanding related to the Ecosystem Approach to Fisheries management (EAF) in the Mediterranean and Black Seas. The existing information available at country level, coming from research and monitoring projects and other types of activities, was explored. The evaluation was done following a standardized protocol and using simple semi-quantitative methods. The results highlighted an overall low-medium degree of fulfilment of the requirements of the EAF, with some differences related to the different issues considered. The highest scores were reported for the knowledge related to fleet structure/behaviour and species/habitat distribution, whereas the lowest scores were reported for modelling, and socio-economic and management issues. Although only semi-quantitative, these results provided an initial picture at a broad regional level on the state of knowledge with a view to a proper implementation of the EAF in the Mediterranean and Black Seas, and identified gaps in scientific knowledge that should be covered.
\end{abstract}

Keywords: ecosystem approach; management; fisheries; Mediterranean; Black Sea.

Evaluación crítica de la comprensión y del conocimiento actuales en el contexto de una aproximación ecosistémica a la gestión pesquera en el Mar Mediterráneo y el Mar Negro

Resumen: Se llevó a cabo una revisión crítica con la intervención de expertos de 17 países para la identificación, resumen y evaluación del conocimiento actual en relación a la Aproximación Ecosistémica a la Gestión Pesquera (EAF) en el Mar Mediterráneo y el Mar Negro. Se explora la información existente a nivel de cada país, derivada de proyectos de investigación y seguimiento, así como otros tipos de actividades. Se llevó a cabo una evaluación siguiendo un protocolo estandardizado y el uso de métodos semi-cuantitativos. Los resultados muestran que en general el grado de cumplimiento con los requerimientos de EAF es bajo-medio, con algunas diferencias relacionadas con los distintos aspectos considerados. Las puntuaciones más elevadas correspondieron al conocimiento relacionado con la estructura de flota y su comportamiento, así como con la distribución espacial de hábitats y especies. Las puntuaciones más bajas correspondieron a aspectos relacionados con la modelización, la socio-economía y la gestión. A pesar de su carácter semi-cuantitativo, estos resultados proporcionan una primera imagen a nivel regional del estado de conocimiento del que se parte para una implementación adecuada de EAF en el Mar Mediterráneo y el Mar Negro y ayuda a identificar las carencias en el conocimiento científico que deben ser corregidas.

Palabras clave: aproximación ecosistémica; gestión; pesquerías; mar Mediterráneo; mar Negro.

Citation/Como citar este artículo: Sartor P., Colloca F., Maravelias C., Maynou F. 2014. Critical assessment of the current understanding/knowledge of the framework of the ecosystem approach to fisheries in the Mediterranean and Black Seas. In: Lleonart J., Maynou F. (eds), The Ecosystem Approach to Fisheries in the Mediterranean and Black Seas. Sci. Mar. 78S1: 19-27. doi: http://dx.doi.org/10.3989/scimar.04021.17B

Editor: Jordi Lleonart.

Received: 8 November 2013. Accepted: 10 January 2014. Published: March 28, 2014.

Copyright: () 2014 CSIC. This is an open-access article distributed under the Creative Commons Attribution-Non Commercial Lisence (by-nc) Spain 3.0. 


\section{INTRODUCTION}

The development of the ecosystem approach to fisheries management (EAF) in the European seas is one of the objectives of the new Common Fisheries Policy in Europe (for the countries belonging to the European Union), as well as one of the priorities identified by the World Summit on Sustainable Development globally (WSSD; United Nations 2002).

Given the human use of their coastal environments for a wide range of conflicting activities (e.g. tourism, diving, shipping, fishing and aquaculture), the Mediterranean and Black Seas are affected by several threats. In a recent attempt to quantify the cumulative human impacts on marine ecosystems, Mediterranean marine ecoregions (see Spalding et al. 2007) were classified among the most impacted ecoregions of the world (Halpern et al. 2008, Micheli et al. 2013a). This situation is also due to the effect of extractive fisheries, whose impact has grown in the last 30 years, leading to the over-exploitation of the main commercial stocks in most areas, along with a variety of well-described direct and indirect negative impacts on the ecosystem (Tudela 2004, Llope et al. 2011, Colloca et al. 2013).

The Black Sea ecosystem has been subjected to dramatic changes since the early 1970 s, because of the combined effect of successive over-exploitation of fish stocks, the increased pollution and eutrophication of the basin, population outbursts of alien planktonic carnivores and strong decadal-scale climatic fluctuations (Daskalov et al. 2007, Oguz and Gilbert 2007).

In both basins the effect of fishing can be exacerbated by the ongoing rapid warming trend, which is believed to act synergistically with fisheries exploitation and to cause quick changes in fish and shellfish fauna, with likely negative impacts on fisheries sustainability (Daskalov et al. 2008, Ben Rais Lasram et al. 2010, Lejeusne et al. 2010).

For all these reasons, the development of the EAF in the Mediterranean and Black Seas is considered a priority, though it is challenged by the inherent sociopolitical complexity of this region, and particularly the high diversity of political and cultural systems and legal jurisdictions (Micheli et al. 2013b). The coastal States in the region often do not share the same management priorities for their fisheries, even if they often exploit the same commercial stocks of fish and shellfish. However, a policy strategy to move in the EAF direction is still far from being developed either at national level (i.e. Mediterranean and Black Sea countries) or international level (i.e. FAO General Fisheries Commission for the Mediterranean Sea) and little progress has been observed in the last few years.

One of the essential components of the EAF is the quantitative analysis of fishing effects by means of ecosystem models. These are mathematical constructs of high complexity that attempt to model the marine ecosystem, ideally with a high degree of realism, in order to assess the effects of fishing on the resource, habitat and stakeholders. Many of the ecosystem models used worldwide in the EAF are based on the mass-balance solution of Ecopath with the Ecosim modelling suite (Walters et al. 2000), but other options exist, such as Osmose (Shin and Cury 2001) and Atlantis (Fulton et al. 2011). Plagányi (2007) provides a comprehensive review of these models and many others. In the Mediterranean and Black Seas, several ecosystem models have been developed (Pranovi et al. 2003, Brando et al. 2004, Coll et al. 2007, 2008, Tsagarakis et al. 2010, Coll and Libralato 2012), but they have not been applied in practice for fisheries management. Owing to the extreme complexity of some of these models and the long development time required (typically, 3-4 years), some authors advocate minimum realistic models (e.g. the GADGET model, Taylor and Stefánsson 2004) or models of intermediate complexity for ecosystem assessments (MICE) (Plagányi et al. 2012), as a reasonable compromise for the application of ecosystem models in the EAF. However, the EAF can also be implemented through the relatively modelfree indicator approach (Cury et al. 2005, Didier et al. 2010, Shin et al. 2010).

In 2011 the European Commission launched the Concerted Action CREAM (Coordinating research in support to application of EAF (Ecosystem Approach to Fisheries) and management advice in the Mediterranean and Black Seas, $7^{\text {th }}$ Framework Programme), involving 22 fisheries research institutions of the Mediterranean and Black Seas focusing on the EAF. The main objective of the project was to establish the guidelines for the application of the EAF in the region and, to this end, to identify the current supporting knowledge.

In the framework of the above Concerted Action the present work was carried out, with the main objective of performing a critical review of the current understanding related to the ecosystem approach of fisheries management (EAF) in the Mediterranean and Black Seas and to assess, by means of expert evaluation, the priority research actions for the development of the EAF. The specific objectives were i) to collate information on the research topics relevant to the EAF financed in the last 10 years either in Mediterranean or the Black Sea; and ii) to carry out a survey among CREAM participants about their current understanding of the capacity to address relevant EAF issues.

\section{MATERIALS AND METHODS}

A critical review of the current understanding related to the EAF in the Mediterranean and Black Seas was carried out, involving experts from 22 institutions of the Mediterranean and Black Seas (Fig. 1). All the available information on research topics relevant to the EAF financed in the last 10 years either in the Mediterranean or the Black Sea was gathered, classified and evaluated.

This exercise was performed according to two main steps:

1) All the information potentially associated with EAF topics related to various types of activities (e.g. research projects, monitoring programmes, advice and other initiatives) carried out by the 22 institutions in the last 10 years was explored in relation to the key aspects 


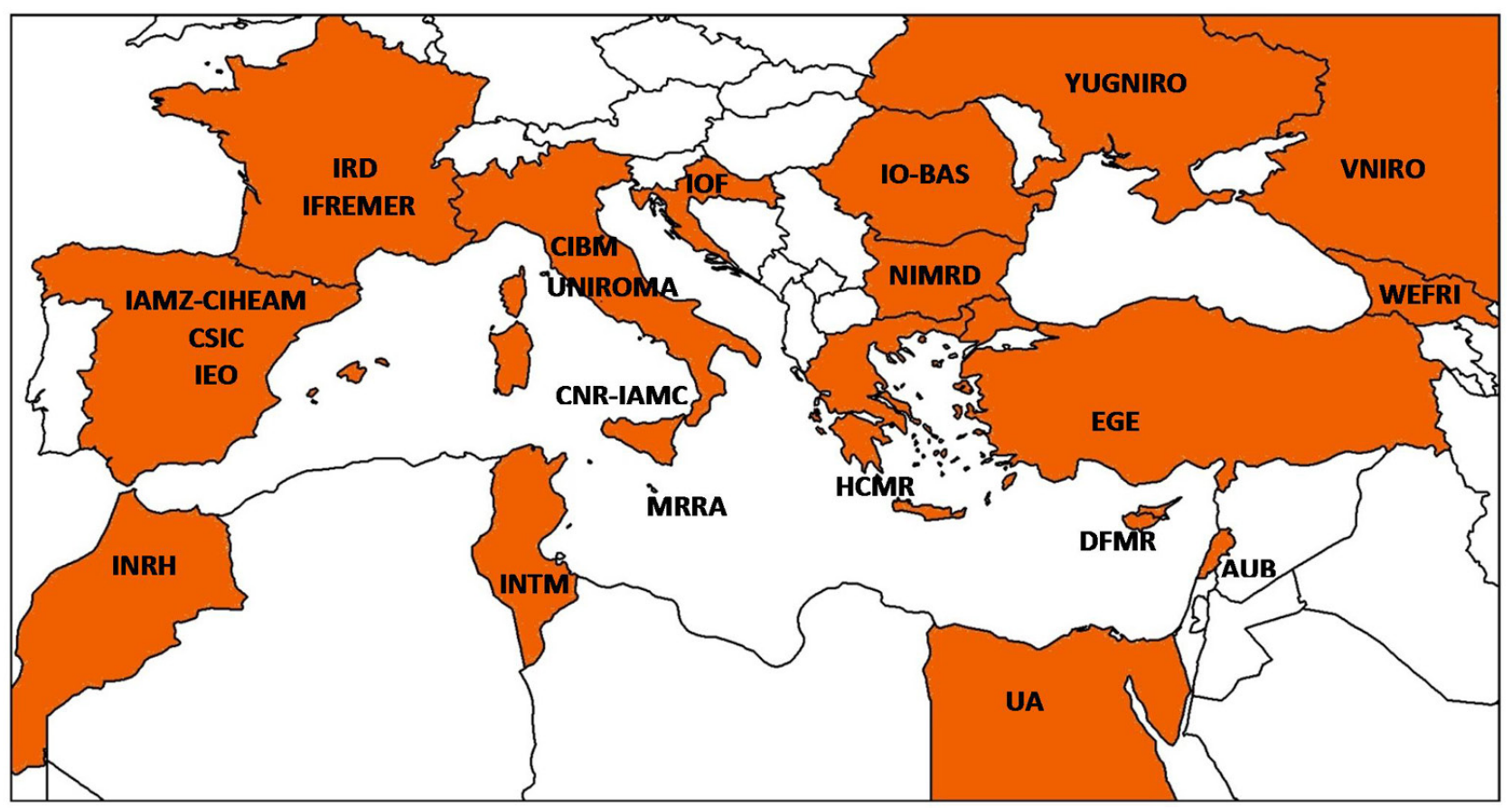

Fig. 1. - Mediterranean and Black Sea countries (coloured areas) and institutions of origin of the experts participating in the present work. IAMZ-CIHEAM, Mediterranean Agronomic Institute of Zaragoza. International Centre for Advanced Mediterranean Agronomic Studies. Zaragoza, Spain; CISC, Agencia Estatal Consejo Superior de Investigaciones Cientificas, Madrid, Spain; HCMR, Hellenic Centre For Marine Research. Athens, Greece; CIBM, Consorzio per il Centro Interuniversitario di Biologia Marina ed Ecologia Applicata "G. Bacci". Livorno, Italy; UNIROMA, Universita degli Studi di Roma "La Sapienza". Roma, Italy; IFREMER, Institut Français de Recherche pour l'Exploitation de la Mer, Issy-Les-Moulineaux, France; IRD, Institut de Recherche pour le Developpement, Marseille, France; IEO, Instituto Español de Oceanografia, Madrid, Spain; CNR-IAMC, Consiglio Nazionale delle Ricerche, Roma, Italy; INRH, Institut National de Recherche Halieutique, Casablanca, Morocco; INSTM, Institut National des Sciences et Technologies de la Mer, Tunis, Tunisia; EGE, Ege Universitesi, Izmir, Turkey; NIMRD, Institutul National de Cercetare-Dezvoltare Marina «Grigore Antipa», Constanta, Romania; IO-BAS, Institute of Oceanology - Bulgarian Academy of Sciences, Varna, Bulgaria; VNIRO, Russian Federal Research Institute of Fisheries and Oceanography, Moscow, Russian Federation; YUGNIRO, Southern Scientific Research Institute of Marine Fisheries and Oceanography, Kerch, Ukraine; AU, Alexandria University, Alexandria, Egypt; IOF, Institute of Oceanography and Fisheries, Split, Croatia; AUB, American University of Beirut, Beirut, Lebanon; MRRA, Ministry for Resources and Rural Affairs, Floriana, Malta; DFMR, Ministry of Agriculture, Natural Resources and Environment of Cyprus, Nicosia, Cyprus; WEFRI, Water Ecology And Fisheries Research Institute, Batumi, Georgia.

associated with the EAF and fishery management. This review was performed according to a common protocol and using a standard template to store and summarize all the information gathered.

The information collected was analysed, classifying each activity according to:

- Its type: research projects, monitoring programmes, advice to public administrations, other.

- Its geographical coverage: local or national scale, Mediterranean or Black Sea scale, wider scale (e.g. Mediterranean and North Atlantic).

- The main topics dealt with: descriptions of fisheries (e.g. characteristics of fleets, fishing capacity/effort, landings), descriptions of species/habitats (e.g. species composition, size/age structure, biological parameters, biocenosis description), modelling (ecological and/or bio-economic), stock assessment and/or management suggestions (suggestions for regulation of fishing effort, for technical measures, for spatial management, etc.).

2) Each expert of the 22 institutions involved in this study provided an evaluation, by means of an overall assessment, of the activities/projects/initiatives taken into account, of the capacity to address, in his or her country, the issues related to the implementation of the EAF. These issues were divided into the following main topics, which reflect the FAO technical guide- lines in research for EAF implementation (FAO 2003):

1) Fisheries structure and fleets.

2) Fisheries impacts and other anthropogenic impacts.

3) Species/habitat knowledge.

4) Socio-economic aspects and modelling (ecosystem and bio-economic).

5) Assessment of management measures.

6) The management process.

7) Monitoring and assessments.

The capacity to address each issue was evaluated according to a simple qualitative scale:

- None, absolute lack of knowledge.

- Low, scarce and scattered knowledge in both space and in time.

- Medium, fairly broad knowledge, but mostly qualitative.

- High, extensive and detailed knowledge, also supported by quantitative analyses.

All the information reviewed from the experts was stored in common tables and pooled and summarized at main basin level (western Mediterranean, central Mediterranean, eastern Mediterranean, Black Sea). A simple score system was used (from 0 to 3 , corresponding to the evaluations ranging from "none" $(0)$ to "high" (3). 
Table 1. - Examples of research projects, monitoring programmes and other initiatives considered for the present study (only the titles are reported).

Action plan against the problems caused by the presence of Lagocephalus sceleratus in the coastal waters of Cyprus

AMPHORE: Marine protected areas: conservation tools for biodiversity and durable management of the marine resources.

Analysis of methodological background for stock size and total allowable catch (TAC) assessment in the Azov-Black Sea basin.

Analysis of trawl discard operations in the central and eastern Mediterranean.

ARCHIMEDES: estimation of maximum net length of trammel nets, gillnets and combined bottom set nets using the volume or the mass of the net.

Assessing small scale fisheries in North Lebanon.

Assessment and forecast of the state of fish resources, the conditions of their existence in the Kerch Strait and adjacent areas of the Black and Azov Seas

Assessment of Black Sea Stocks, Turkey.

Assessment of the extent of present Cetacea by-catch and strandings in the Romanian Black Sea area.

BADMINTON: By-catch and discards: management indicators, trends and location.

BEMMFISH: Bio-economic Modelling of Mediterranean Fisheries.

BEMTOOL: Development of an integrated bio-economic modelling tool to develop and support multi-objective approaches for fisheries management. Identification of the main species and fleet segments/metier covering a suitable proportion of total catches/landings and total revenues of the main métier involved in multispecies multiple gears demersal fisheries in different Mediterranean sub-regions

BIHARE: Fishery biology of the benthic resources in Tunisia.

Biological variables of the Data Collection Framework - European Commission, EC Reg. 199/2008.

BIOMEX: Assessment of Biomass export from marine protected areas \& its impacts on fisheries in the western Mediterranean Sea.

Determination of the demersal stock in the southwestern Black Sea.

ECOMARE: Status of knowledge of the reserve effect in marine ecosystems.

EMBIOS: End-to-end Modelling and Indicators for BIOdiversity Scenarios.

EMPAFISH: European marine protected areas as tools for fisheries management and conservation.

EnviEFH: Environmental Approach to Essential Fish Habitat Designation.

Establishment of a Fishery Restricted Area (FRA) in the Gulf of Lions.

Estimate the fishing effort necessary for the development of marine living resources in areas of fisheries in the Azov-Black Sea basin

Evaluation of the Southern Greek Anchovy Stocks.

Evaluation of the Southern Greek Sardine Stocks.

EVOMED: the 20th Century evolution of Mediterranean exploited demersal resources under increasing fishing intensity.

Fishery Along the Aegean Coast (Turkey).

Fishery of smooth-hound shark (Mustelus mustelus) with gill nets and long-line in and around Izmir Bay.

GRUND: Demersal resources evaluation by trawl surveys. Italian national group of evaluation of demersal resources.

INDECO: Development of Indicators of Environmental Performance of The Common Fisheries Policy

Investigation of new marine biological resources in the deep waters of the Ionian Sea.

Investigation on the Bio-Ecology and Population Dynamics of Demersal Fishes in Saros Bay - Northern Aegean Sea.

Investigations on Some Population Characteristics and Fishery of Bluefish (Pomatomus saltatrix L. 1758) in Marmara Region.

Investigations to improve species and size selectivity in Mersin Bay Trawl Fisheries.

KnowSeas: Knowledge-based sustainable management for Europe's Seas.

MADE: Mitigating adverse ecological impacts of open ocean fisheries.

Marine Ecosystem Conservation and Promotion of Sustainable Use

Marine reserve network for the Lebanese waters.

MEDIAS: Mediterranean Acoustic Surveys.

MEDISEH: compilation and mapping of environmental and fisheries-related information in the Mediterranean Sea by means of Geographical Information Systems (GIS): integration and mapping of the spatial information on sensitive habitats: a) habitats protected under the Mediterranean regulation; b) nursery areas and spawning aggregations of demersal and small pelagic fish and c) areas under any form of protection within national and international legislation.

Mediterranean deep-sea ecosystems

MEDITS: Mediterranean trawl survey (EC reg. 199/2008).

MedMPA: regional project for the development of marine and coastal protected areas in the Mediterranean region.

MEDPOL: Programme for the assessment and control of pollution of the Mediterranean.

MELMARINA: Monitoring and modelling coastal lagoons: making management tools for aquatic resources in North Africa.

MESMA: Monitoring and Evaluation of Spatially Managed Areas

Modern basis of forming of fishery resources of the Azov-Black Sea basin in conditions of climate change and human activity

Monitoring of coastal waters within the framework of Article 8 of the Water Framework Directive (2000/60/EC) in Cyprus.

NURSERY: Spatio-temporal identification of concentration areas of juveniles of the main demersal species and geographical location of nursery areas in the Italian seas

Overview of the conservation status of the marine fishes of the Mediterranean Sea.

PERSEUS: Policy-oriented marine environmental research in the Southern European Seas.

POLYPECHE: Coastal multigear fishermen, management and sustainable coastal fisheries.

RECS: Integral study of a submarine canyon in the western Mediterranean (Blanes Canyon). Application to the exploitation of the red shrimps.

REDS: Status of deep-sea red shrimps in the central and eastern Mediterranean Sea

RE-SHIO: Exploration of pristine red shrimp resources and comparison with exploited ones in the Ionian Sea

RESPONSE: Response of benthic communities and sediment to different regimens of fishing disturbance

Review of the Current Status of Fisheries Resources and Utilization in Georgia.

SESAME: Southern European Seas: Assessing and Modelling Ecosystem.

SGMED (STECF): Assessment of EU Mediterranean Stocks.

SGMED-(STECF). Assessment of EU Black Sea stocks.

Socio-economic development of the community of the fishermen of Tyre.

Stock assessment of barracuda, genus Sphyraena, along the Egyptian Mediterranean coast.

Strengthening the system of marine protected areas of Turkey.

The Black Sea salmon strategy of conservation, rehabilitation and management.

The bluefin tuna fishery in the Greek seas.

The execution of specific assessments in the coastal areas of Port Said (Egypt): fishery.

The present status of the fishery and information system in Lebanon.

The study of population dynamics and status of stocks of marine living resources of the Black and Azov Seas

The study of the Georgian coastal zone commercial fish stocks.

VALFEZ: Value of exclusion zones as a fisheries management tool in Europe.

VECTORS: Vectors of change in oceans and seas marine life, impact on economic sectors.

ZTB: No-take Marine Protected Areas in Italian seas. 
Table 2. - Classification of the information gathered according to the type of activity. The values reported are percentage contributions. The results are presented by main basins.

\begin{tabular}{|c|c|c|c|c|}
\hline \multirow[b]{2}{*}{$\begin{array}{l}\text { Source basin of the } \\
\text { information }\end{array}$} & \multicolumn{4}{|c|}{ Type of information } \\
\hline & Research projects & Monitoring activities & $\begin{array}{l}\text { Support activities for the Public } \\
\text { Administrations }\end{array}$ & Others \\
\hline WEST MED & 53.3 & 20.0 & 8.4 & 18.3 \\
\hline EAST MED & 42.5 & 21.9 & 12.4 & 23.2 \\
\hline CENTR MED & 46.2 & 30.7 & 15.4 & 7.7 \\
\hline BLACK SEA & 34.5 & 16.4 & 23.6 & 25.5 \\
\hline Overall & 44.9 & 20.9 & 12.3 & 21.9 \\
\hline
\end{tabular}

Table 3. - Classification of the information gathered according to the geographical areas covered by each activity. The values reported are the percentage contributions. The results are presented by main basins.

\begin{tabular}{lccc}
\hline Source basin of the information & Local/national & $\begin{array}{c}\text { Geographical coverage of the information } \\
\text { All Mediterranean or Black } \\
\text { Sea }\end{array}$ & \multicolumn{2}{c}{$\begin{array}{c}\text { Wider areas } \\
\text { WEST MED }\end{array}$} & 19.4 & 66.7 & 23.9 \\
CENTR MED & 33.3 & 58.2 & 9.1 \\
EAST MED & 32.7 & 69.0 & 9.5 \\
BLACK SEA & 21.5 & & \\
\hline
\end{tabular}

Table 4. - Classification of the information gathered according to the main topics of each activity. The values reported are the percentage contributions. The results are presented by main basins.

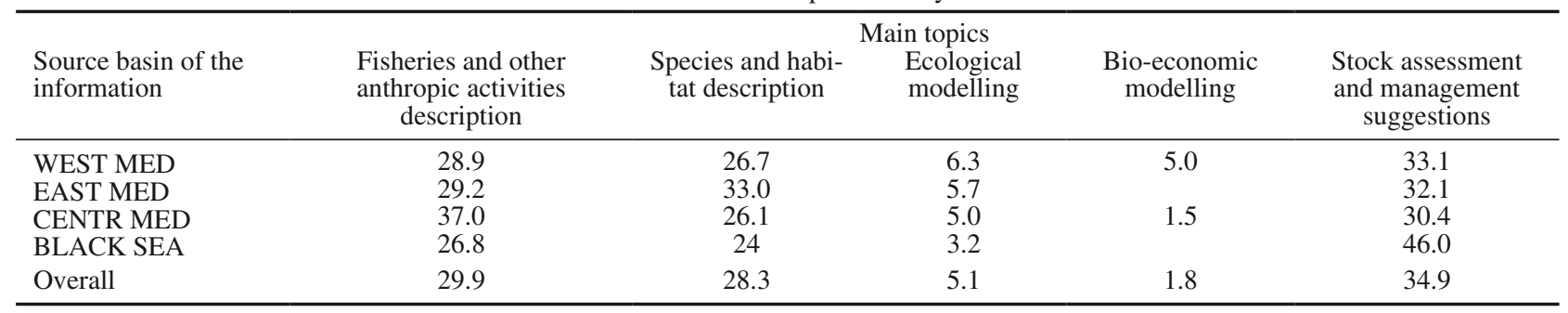

All this work was finalized in a specific workshop held at the FAO GFCM headquarters in Rome on 30-31 May 2012. The workshop was fundamental to standardize this common work and the procedure of analysis.

\section{RESULTS}

Information coming from about two hundred different types of activities possibly related to the EAF context was gathered by the experts involved in this study. Table 1 provides an example of several research projects/monitoring programmes/advice/other initiatives, showing how this information is wide, detailed and, in many cases, very heterogeneous.

Tables 2, 3 and 4 summarize the information gathered according to the type of activity, the geographical coverage and the main topics dealt with. No substantial differences were detected among the four main basins considered.

Most of the information considered $(34.5 \%$ to $53.3 \%$ according to each basin) is related to research projects (Table 2 ). Information from monitoring programmes was also collected in large amounts $(16.4 \%$ to $31 \%$ ), mostly concerning routinely and standardized fishery-dependent or -independent data collection programmes such as those running under the European Union Data Collection Framework. Activities related to various types of advices to support public administrations in fishery management represent $8 \%$ to $24 \%$ of the information collected, with the highest percentage being observed for the Black Sea.
As regards geographical coverage, the majority of the activities analysed $(56.7 \%$ to $69.0 \%)$ of the total (Table 3 ) are performed in fairly wide areas, but within the boundaries of the Mediterranean and Black Seas. Only for the western Mediterranean institutions, a large proportion of the activities considered affect very wide areas.

The information collected deals with three main topics (Table 4):

- From $26.8 \%$ to $37 \%$ of the information deals with descriptions of fisheries characteristics (e.g. characterization of fleets, fishing gears, distribution of fishing effort, statistic on landings, CPUE, etc.).

- Studies at species level (e.g. distribution, biology and ecology) or habitat level (e.g. species assemblages and species list) account for $24 \%$ to $33 \%$ of the information considered.

- From $30 \%$ to $46.2 \%$ of the activities analysed provide assessments at single stock level or management suggestions.

- A small proportion of the information gathered (6\% at most, according to the basin considered) is related to modelling from both the ecological and the bio-economic point of view.

In spite of the large amount, the information reviewed was highly heterogeneous, making it difficult to draw a picture on how the EAF issues are addressed in each country. This heterogeneity is mainly due to the following reasons:

- Different types of projects/initiatives considered.

- Differences in the "interpretation" of the available information in the EAF context. 


\section{OVERALL RESULTS}

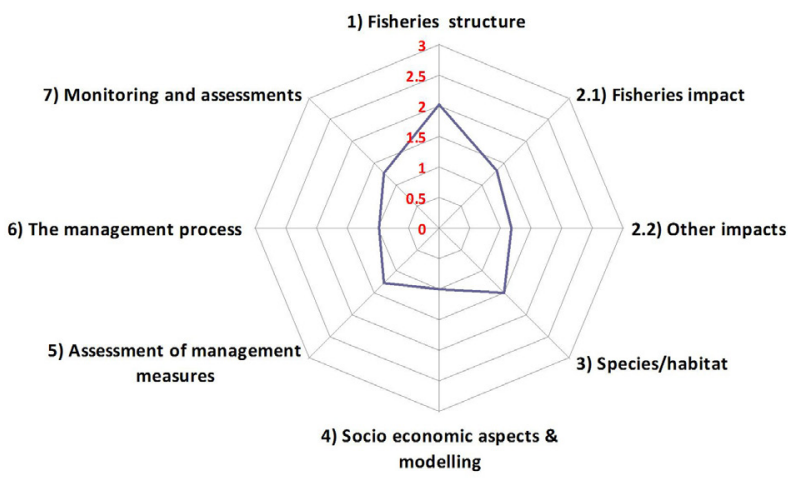

Fig. 2. - Radar graph showing the overall overview of the expert evaluation on the capacity to address the EAF issues. Scores range from 0 to 3 (from null to high capacity to address each issue related to the EAF).

- The different nature of the partners (universities, national research institutions, governmental institutions, private research institutions, etc.).

\section{WESTERN MEDITERRANEAN}
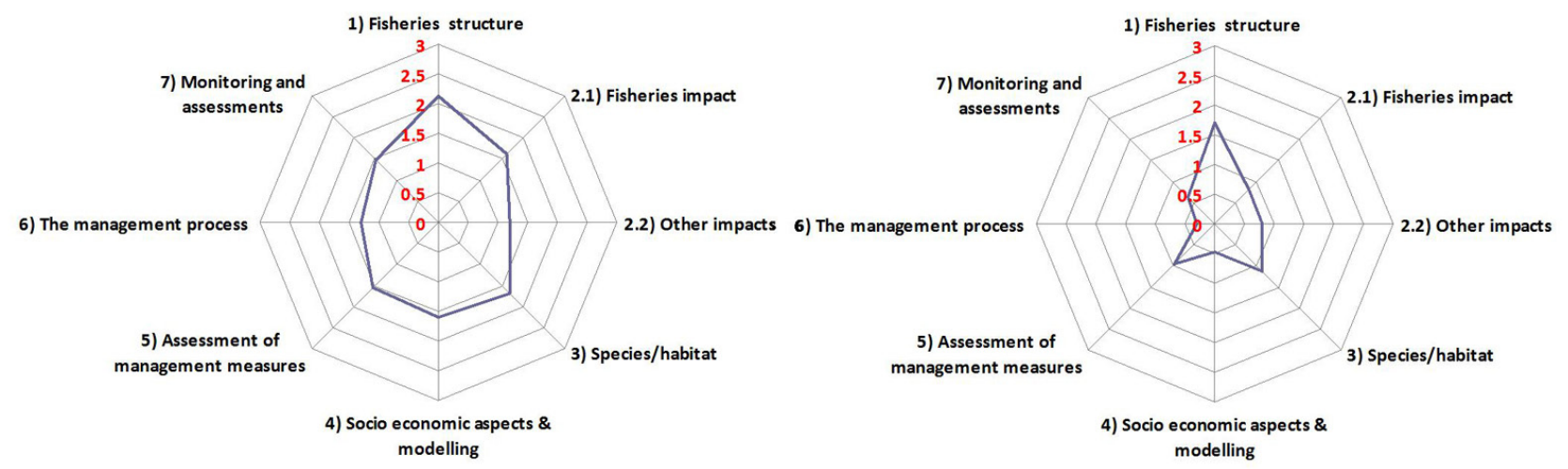

CENTRAL MEDITERRANEAN

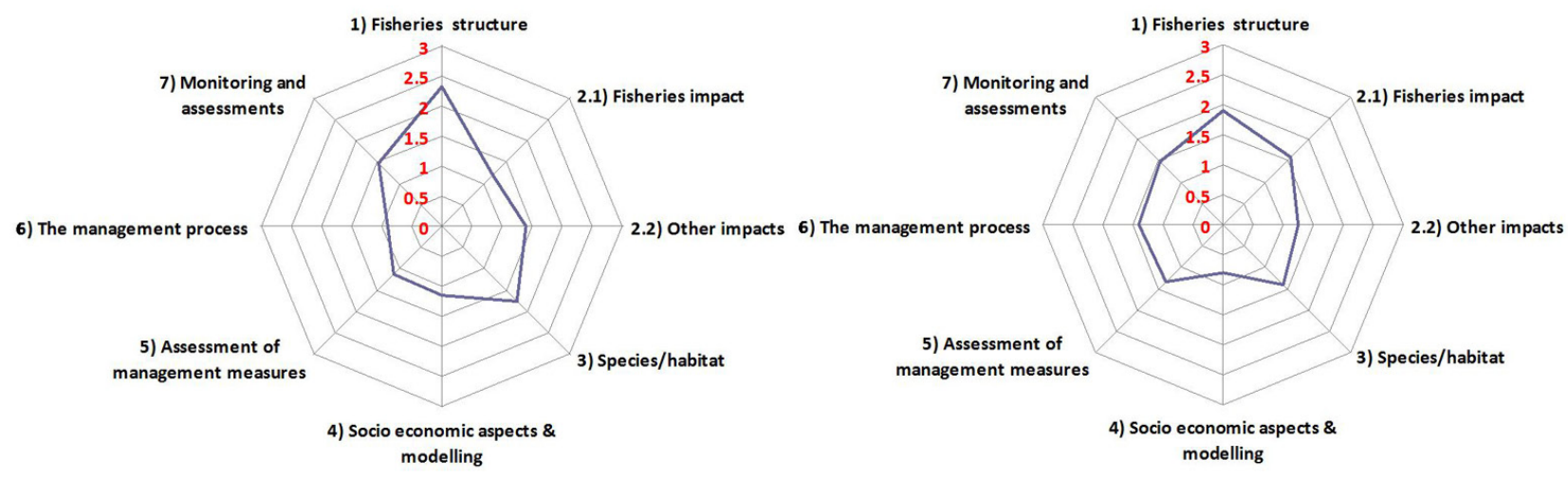

Fig. 3. - Radar graphs showing the overall overview of the expert evaluation on the capacity to address the EAF issues according to main basins. Scores ranges from 0 to 3 (from null to high capacity to address each issue related to the EAF).
Therefore an effort to harmonize and evaluate all the information available under the EAF point of view was deemed essential and it was carried out during the specific CREAM workshop held in May 2012. After the discussions and the standardized work performed during the workshop, an overview based on the expert evaluations was produced. Table 5 shows in detail the results obtained, according to a semi-quantitative score system. The scores were also summarized following the main EAF issues and presented according to radar graphs (Figs 2 and 3). gree of fulfilment of the requirements of the EAF in the Mediterranean and Black Seas, with some differences related to the different issues considered.

In general, the highest scores were reported for the knowledge related to fleet structure/behaviour (average score $=2$ ) and species/habitat characteristics (average score $=1.5$ ), while the lowest ones were reported for modelling, socio-economic and management issues (average score $=0.1$ ). No substantial differences were detected according to the main basins considered.
The results highlighted an overall low-medium de-

\section{EASTERN MEDITERRANEAN}

BLACK SEA 
Table 5. - Summary of the results of the expert evaluation on the capacity to address the EAF issues, according to main basins and main topics related to the EAF. Scores range from 0 to 3 (from null to high capacity to address each issue related to the EAF).

\begin{tabular}{|c|c|c|c|c|c|}
\hline & West Med & Centr Med & East Med & Black Sea & Overall average \\
\hline $\begin{array}{l}1 \text { - Fisheries: structure and behaviour } \\
\text { Fleets composition, fishing capacity, gears } \\
\text { Landings and LPUE } \\
\text { Fishing grounds, fishing pattern } \\
\text { Discarding }\end{array}$ & $\begin{array}{l}2.6 \\
2.4 \\
2.3 \\
1.2\end{array}$ & $\begin{array}{l}2.8 \\
2.8 \\
2.2 \\
1.4\end{array}$ & $\begin{array}{l}2.4 \\
1.6 \\
1.6 \\
1.2\end{array}$ & $\begin{array}{l}2.6 \\
1.8 \\
2.0 \\
1.2\end{array}$ & \\
\hline Average value & 2.1 & 2.3 & 1.7 & 1.9 & 2.0 \\
\hline $\begin{array}{l}2.1 \text { - Fisheries impact assessment } \\
\text { On target stocks } \\
\text { On non-target stocks (by-catch, discards) } \\
\text { Effects on ecosystem/habitat }\end{array}$ & $\begin{array}{l}2.1 \\
1.6 \\
1.2\end{array}$ & $\begin{array}{l}1.6 \\
1.0 \\
1.0\end{array}$ & $\begin{array}{l}1.0 \\
0.8 \\
0.6\end{array}$ & $\begin{array}{l}1.8 \\
1.4 \\
1.6\end{array}$ & \\
\hline Average value & 1.6 & 1.2 & 0.8 & 1.6 & \\
\hline 2.2 - Other anthropogenic impacts & 1.2 & 1.4 & 0.8 & 1.3 & 1.2 \\
\hline $\begin{array}{l}3 \text { - Species/habitat knowledge } \\
\text { Species compsition/assemblages } \\
\text { Stock boundaries (e.g. genetic studies) } \\
\text { Endangered and alien species } \\
\text { Sensitive and Essential Fish Habitats (SH, EFH) } \\
\text { Ecosysem functioning and modelling }\end{array}$ & $\begin{array}{l}2.6 \\
0.8 \\
1.8 \\
2.3 \\
1.0\end{array}$ & $\begin{array}{l}2.6 \\
1.2 \\
2.0 \\
2.2 \\
0.8\end{array}$ & $\begin{array}{l}2.2 \\
0.2 \\
1.8 \\
1.4 \\
0.0\end{array}$ & $\begin{array}{l}2.2 \\
1.0 \\
1.6 \\
1.6 \\
0.6\end{array}$ & \\
\hline Average value & 1.7 & 1.8 & 1.1 & 1.4 & 1.5 \\
\hline $\begin{array}{l}4 \text { - Socio-economic aspects and modelling } \\
\text { Factors influencing the day-to-day behaviour of fishing vessels } \\
\text { Socio-economic assessments } \\
\text { Multispecies and bio-economic models }\end{array}$ & $\begin{array}{l}1.5 \\
1.7 \\
1.6\end{array}$ & $\begin{array}{l}1.0 \\
1.6 \\
0.8\end{array}$ & $\begin{array}{l}0.2 \\
0.8 \\
0.4\end{array}$ & $\begin{array}{l}0.6 \\
1.6 \\
0.2\end{array}$ & \\
\hline Average value & 1.6 & 1.1 & 0.5 & 0.8 & 1.0 \\
\hline $\begin{array}{l}5 \text { - Assessment of management measures } \\
\text { Fishing capacity/effort limitations } \\
\text { Spatio-temporal management (e.g. fishing closures, MPAs) } \\
\text { Gear technology research (e.g. selectivity, new gears) } \\
\text { Restocking } \\
\text { Artificial habitats }\end{array}$ & $\begin{array}{l}1.8 \\
2.0 \\
1.8 \\
0.8 \\
1.4\end{array}$ & $\begin{array}{l}1.6 \\
1.4 \\
1.4 \\
0.4 \\
0.8\end{array}$ & $\begin{array}{l}1.4 \\
1.4 \\
1.4 \\
0.2 \\
0.4\end{array}$ & $\begin{array}{l}1.8 \\
1.8 \\
1.4 \\
0.8 \\
1.0\end{array}$ & \\
\hline Average value & 1.6 & 1.1 & 1.0 & 1.4 & 1.3 \\
\hline $\begin{array}{l}6 \text { - The management process } \\
\text { Traditional ecological Knowledge (TEK) into management } \\
\text { Participatory process in general }\end{array}$ & $\begin{array}{l}1.2 \\
1.4\end{array}$ & $\begin{array}{l}0.8 \\
1.0\end{array}$ & $\begin{array}{l}0.2 \\
0.4\end{array}$ & $\begin{array}{l}1.6 \\
1.2\end{array}$ & \\
\hline Average value & 1.3 & 0.9 & 0.3 & 1.4 & 1.0 \\
\hline $\begin{array}{l}7 \text { - Monitoring and assessments } \\
\text { The state of the ecosystems/habitats } \\
\text { Fisheries resource status/stock assessment } \\
\text { Socio-economic aspects } \\
\text { Analytical techniques for decision making } \\
\text { Indicators }\end{array}$ & $\begin{array}{l}1.4 \\
2.4 \\
2.1 \\
0.2 \\
1.4\end{array}$ & $\begin{array}{l}1.6 \\
2.2 \\
1.6 \\
0.4 \\
1.6\end{array}$ & $\begin{array}{l}0.8 \\
1.2 \\
0.8 \\
0.2 \\
0.2\end{array}$ & $\begin{array}{l}1.8 \\
1.6 \\
1.4 \\
1.0 \\
1.6\end{array}$ & \\
\hline Average value & 1.5 & 1.5 & 0.6 & 1.5 & 1.3 \\
\hline
\end{tabular}

\section{DISCUSSION}

The most important finding of this work is that the EAF in the Mediterranean has much work to do. Although only semi-quantitative, the current results could provide an initial global picture at a wide geographical level to properly address the implementation of the EAF in the Mediterranean and Black Seas. Essentially, this exercise helped identify which aspects of EAF need to be reinforced by future research programmes and training actions. Our results show that knowledge on fisheries characterization, stocks and habitats is relatively high. On the other hand, information on the management process and socio-economic aspects of fisheries is relatively poor. The sustainable exploitation of marine living resources (including fisheries) and conservation of natural resources has been a top priority on the agenda of international organizations and States during the last two decades (for instance UNEP/MAP 2012, United Nations 2002), and the over-exploitation of stocks and impact of fishing activities on the environment has led to widespread demands for sustainable and responsible exploitation of stocks (for instance, the Marine Strategy Framework Directive 2008, COM 2012 for the EU countries, Black Sea Commission 2008 for the Black Sea), but these priorities will not be effectively addressed with unbalanced knowledge among the different disciplines that hinders the effective application of the EAF. Management of fishery stocks is often complex and difficult, and this situation is exacerbated in the case of the Mediterranean and Black Sea fisheries with highly migratory, straddling and cross-border stocks. Data for the assessment and management of such stocks are gathered by different countries and supported by the European Commission and Regional Fisheries Management Organizations (RFMOs), such as the GFCM and the International Commission for the Conservation of Atlantic Tunas (ICCAT). However, due to the complexity of addressing research and management of shared stocks, coordinated efforts to develop scientific knowledge between the RFMOs and coastal States have not always been made. This has also been the case in both the Mediterranean and Black Seas, where the management of 
available marine biological resources is fragmented. Evidently, there has been a need to move towards a wider geographic and regional management of fisheries. To this end, the CREAM Concerted Action advanced cooperative research and can be regarded as an important step towards effective management of stocks exploited by various countries.

With few exceptions, current advice on the exploitation of fish stocks in the Mediterranean Sea is based on single-species assessments, whereas there is a pressing need for more ecosystem-oriented fisheries management and integration of ecosystem and socio-economic considerations into assessment procedures (Coll et al. 2013). In the Mediterranean and Black Seas, existing national fisheries research agencies and international bodies related to management (GFCM, ICCAT, EU, $\mathrm{BSC}, \mathrm{RAC} / \mathrm{SPA}, \mathrm{FAO}$ ) have conducted, jointly or individually, a considerable amount of research on fisheries assessment and management that is conducive to the application of the EAF in both regions.

The CREAM Coordination and Support Action set up the basis for a network of research organizations by establishing a participatory dialogue between researchers and assessment and management bodies in order to define the research needs for implementing an EAF in the Mediterranean and Black Seas and provide scientific advice. To this end, the CREAM project claims that the EAF aims "to balance diverse societal objectives, by taking into account the knowledge and uncertainties about biotic, abiotic and human components of ecosystems and their interactions and applying an integrated approach to fisheries within ecologically meaningful boundaries" (FAO 2003).

\section{ACKNOWLEDGEMENTS}

We thank the CREAM Partners for providing the data used for the analyses: Marina Panayotova (IOBAS, Bulgaria); Vjekoslav Tičina (IOF, Croatia); Yianna Samuel-Rhoads (DFMR-MANRE, Nicosia, Cyprus); Abdel-Fattah El-Sayed, (Alexandria University, Egypt); Marta Coll (IRD \& IFREMER, France); Joël Vigneau (IFREMER, France); Guranda Makharadze (WEFRI, Georgia); Germana Garofalo (CNR, Italy); Michel Bariche (American University of Beirut, Lebanon); Leyla Knittweis (MRRA, Malta); Abdelaziz Zoubai (INRH, Morocco); Gheorghe Radu (NIMRD, Romania); Dmitry Vasilyev (VNIRO, Russia) Federico Alvarez (IEO, Spain); Jordi Lleonart (ICM-CSIC, Spain); Skander Ben Salem (INSTM, Tunisia); Adnan Tokaç (Ege University, Turkey), Boris Trotsenko (YugNIRO, Ukraine).

\section{REFERENCES}

Ben Rais Lasram F., Guilhaumon F. Albouy C., Somot S., Thuiller W., Mouillot D. 2010. The Mediterranean Sea as a 'cul-de-sac' for endemic fishes facing climate change. Global Change Biol. 16: 3233-3245. http://dx.doi.org/10.1111/j.1365-2486.2010.02224.x

Black Sea Commission 2008. Black sea transboundary diagnostic analysis. Black Sea Commission, Brando, V. E. Ceccarelli, R., Libralato, S., Ravagnan, G. 2004. Assessment of environmental management effects in a shallow water basin using mass- balance models. Ecol. Modell. 172(2-4): 213-232.

Coll M., Libralato S. 2012. Contributions of food web modelling to the ecosystem approach to marine resource management in the Mediterranean Sea. Fish Fish. 13(1): 60-88. http://dx.doi.org/10.1111/j.1467-2979.2011.00420.x

Coll M., Santojanni A., Palomera I., Tudela S., Arneri E. 2007. An ecological model of the Northern and Central Adriatic Sea: Analysis of ecosystem structure and fishing impacts. J. Mar. Syst. 67(1-2): 119-154 http://dx.doi.org/10.1016/j.jmarsys.2006.10.002

Coll M., Palomera I., Tudela S., Dowd M. 2008. Food-web dynamics in the South Catalan Sea ecosystem (NW Mediterranean) for 1978-2003. Ecol. Model. 217(1-2): 95-116 http://dx.doi.org/10.1016/j.ecolmodel.2008.06.013

Coll M., Cury P., Azzurro E., Bariche M., Bayadas G., Bellido J.M., Chaboud C., Claudet J., El-Sayed A.F., Gascuel D., Knittweis L., Pipitone C., Samuel-Rhoads Y., Taleb S., Tudela S., Valls A. 2013. The scientific strategy needed to promote a regional ecosystem-based approach to fisheries in the Mediterranean and Black Seas. Rev. Fish Biol. Fish. http://dx.doi.org/10.1007/s11160-013-9305-y

Colloca F., Cardinale M., Maynou F., Giannoulaki M., Scarcella G. Jenko K., Bellido J.M., Fiorentino F. 2013. Rebuilding Mediterranean fisheries: a new paradigm for ecological sustainability. Fish Fish. 14: 89-109.

Cury P.M., Shannon L.J., Roux J. P., Daskalov G. M., Jarre A. 2005. Trophodynamic indicators for an ecosystem approach to fisheries. ICES J. Mar. Sci. 62(3): 430-442. http://dx.doi.org/10.1016/j.icesjms.2004.12.006

Daskalov G. M., Grishin A., Rodionov S., Mihneva V. 2007. Trophic cascades triggered by overfishing reveal possible mechanisms of ecosystem regime shifts. PNAS 104: 10518-10523. http://dx.doi.org/10.1073/pnas.0701100104

Daskalov G. M., Prodanov K., Zengin M. 2008. The Black Sea Fisheries and Ecosystem Change: Discriminating Between Natural Variability and Human-Related Effects. Am. Fish. Soc. Symp. 49(2): 1649-1664

EU COM 2011. Communication from the Commission concerning a consultation on Fishing Opportunities. 298 final, 15 pp.

FAO 2003. The ecosystem approach to fisheries. FAO Technical Guidelines for Responsible Fisheries, No. 4 (Suppl. 2). FAO Fisheries Department. Rome, FAO, 112 p.

Fulton E.A., Link J.S., Kaplan I.C., Savina-Rolland M., Johnson P. Ainsworth C., Horne P., Gorton R., Gamble R.J., Smith A.D.M., Smith D.C. 2011. Lessons in modelling and management of marine ecosystems: the Atlantis experience. Fish Fish. 12: 171-188. http://dx.doi.org/10.1111/j.1467-2979.2011.00412.x

Halpern B.S., Waldbridge S., Selkoe K.A, Kappel C.V., Micheli F., D’Agrosa C., Bruno J.F., Casey K., Ebert C., Fox H.E., Fujita R., Heinemann D., Lenihan H.S., Madin E.M.P., Perry M.T., Selig E.R., Spalding M., Steneck R., Watson R. 2008. A global map of human impact on marine ecosystems. Science 319: 948-952. http://dx.doi.org/10.1126/science.1149345

Lejeusne C., Chevaldonné P., Pergent-Martini C., Boudouresque C.F., Pérez T. 2010. Climate change effects on a miniature ocean: the highly diverse, highly impacted Mediterranean Sea. Trends Ecol. Evol. 25: 250-260. http://dx.doi.org/10.1016/j.tree.2009.10.009

Llope M., Daskalov G.M., Rouyer T.A., Mihneva V., Chan K.-S. 2011 Overfishing of top predators eroded the resilience of the Black Sea system regardless of the climate and anthropogenic conditions. Glob. Change Biol. 17(3): 1251-1265. http://dx.doi.org/10.1111/j.1365-2486.2010.02331.x

Micheli F., Halpern B.S., Walbridge S., Ciriaco S., Ferretti F. 2013a. Cumulative Human Impacts on Mediterranean and Black Sea Marine Ecosystems: Assessing Current Pressures and Opportunities. PLoS ONE 8(12): e79889. http://dx.doi.org/10.1371/journal.pone.0079889

Micheli F., Levin N, Giakoumi S., Katsanevakis S, Abdulla A., Coll M., Fraschetti S., Kark S. 2013b. Setting Priorities for Regional Conservation Planning in the Mediterranean Sea. PLoS ONE 8(4): e59038 http://dx.doi.org/10.1371/journal.pone.0059038

Marine Strategy Framework Directive 2008. Directive 2008/56/ of the European Parliament and of the Council of 17 June 2008 establishing a framework for community action in the field of marine environmental policy (Marine Strategy Framework Directive). Official Journal of the European Union, 25.06.2008.

Oguz T., Gilbert D. 2007. Abrupt transitions of the top-down controlled Black Sea pelagic ecosystem during 1960-2000: 
evidence for regime shifts under strong fishery exploitation and nutrient enrichment modulated by climate-induced variations. Deep-Sea Research I 54: 220-242

http://dx.doi.org/10.1016/j.dsr.2006.09.010

Plagányi E. E. 2007. Models for an ecosystem approach to fisheries. FAO Fish. Tech. Paper 477: 1-126.

Plagányi E. E., Punt A.E., Hillary R., Morello E.B., Thebaud O., Hutton T., Pillans R.D., Thorson J.T., Fulton E.A., Smith A.D.M., Smith F., Bayliss P., Haywood M., Lyne V., Rothlisberg P.C. 2012. Multispecies fisheries management and conservation: tactical applications using models of intermediate complexity. Fish Fish. http://dx.doi.org/10.1111/j.1467-2979.2012.00488.x

Pranovi F., Libralato S., Raicevich S. 2003. Mechanical clam dredging in Venice lagoon: Ecosystem effects evaluated with a trophic mass-balance model. Mar. Biol. 143(2): 393-403. http://dx.doi.org/10.1007/s00227-003-1072-1

Shin Y-J., Cury P. 2001. Exploring fish community dynamics through size-dependent trophic interactions using a spatialized individual-based model. Aquat. Living Resour., 14: 65-80. http://dx.doi.org/10.1016/S0990-7440(01)01106-8

Shin Y.-J., Shannon L.J., Bundy A., Coll M., Aydin K., Bez N., Blanchard J. L., Borges M.F., Diallo I., Diaz E., Heymans J.J., Hill L., Johannesen E., Jouffre D., Kifani S., Labrosse P., Link J. S., Mackinson S., Masski H., Mollmann C., Neira S., Ojaveer H., Ould Mohammed Abdallahi K., Perry I., Thiao D., Yemane D., Cury P.M. 2010. Using indicators for evaluating, comparing, and communicating the ecological status of exploited marine ecosystems. 2. Setting the scene. ICES J. Mar. Sci. 67(4): 692-716. http://dx.doi.org/10.1093/icesjms/fsp294
Spalding M.D., Fox H.E., Allen G.R., Davidson N., Ferdana Z.A., Finlayson M., Halpern B.J., Jorge M.A., Lombana A., Lourie S.A., Martin K.D., McManus E., Molnar J., Recchia C.A., Robertson J. 2007. Marine ecoregions of the world: A bioregionalization of coastal and shelf areas. BioScience 57: 573-583. http://dx.doi.org/10.1641/B570707

Taylor L., Stefansson G. 2004. Gadget models of cod-capelinshrimp interactions in Icelandic waters. ICES CM 2004/FF: 29.

Tsagarakis K.; Coll M., Giannoulaki M., Somarakis S., Papaconstantinou C. 2010. Food-web traits of the North Aegean Sea ecosystem (Eastern Mediterranean) and comparison with other Mediterranean ecosystems. Est. Coast. Shelf Sci. 88(2): 233248. http://dx.doi.org/10.1016/j.ecss.2010.04.007

Tudela S. 2004. Ecosystem effects of fishing in the Mediterranean: an analysis of the major threats of fishing gear and practices to biodiversity and marine habitats. Studies and Reviews. General Fisheries Commission for the Mediterranean. No. 74. Rome, FAO. 2004, 44 pp.

United Nations 2002. Plan of Implementation of the World Summit on Sustainable Development. Retrieved from http://www. un.org/esa/sustdev/documents/WSSD_POI_PD/English/ WSSD PlanImpl.pdf (accessed November 2013).

UNEP/MAP 2012. State of the Mediterranean marine and coastal environment. Mediterranean Action Plan, Athens, $96 \mathrm{pp}$.

Walters C.J., Pauly D., Christensen V., Kitchell J.F. 2000. Representing density dependent consequences of life history strategies in aquatic ecosystems: ECOSIM II. Ecosystems 3: 70-83. http://dx.doi.org/10.1007/s100210000011 